\title{
TU/e EmonONEN

\section{Temperature retrieval algorithm for brain temperature monitoring using microwave brightness temperatures}

\section{Citation for published version (APA):}

Leeuwen, van, G. M. J., Hand, J. W., Kamer, van de, J. B., \& Mizushina, S. (2001). Temperature retrieval algorithm for brain temperature monitoring using microwave brightness temperatures. Electronics Letters, 37(6), 341-342. https://doi.org/10.1049/el:20010269

DOI:

10.1049/el:20010269

Document status and date:

Published: 01/01/2001

\section{Document Version:}

Publisher's PDF, also known as Version of Record (includes final page, issue and volume numbers)

\section{Please check the document version of this publication:}

- A submitted manuscript is the version of the article upon submission and before peer-review. There can be important differences between the submitted version and the official published version of record. People interested in the research are advised to contact the author for the final version of the publication, or visit the $\mathrm{DOI}$ to the publisher's website.

- The final author version and the galley proof are versions of the publication after peer review.

- The final published version features the final layout of the paper including the volume, issue and page numbers.

Link to publication

\section{General rights}

Copyright and moral rights for the publications made accessible in the public portal are retained by the authors and/or other copyright owners and it is a condition of accessing publications that users recognise and abide by the legal requirements associated with these rights.

- Users may download and print one copy of any publication from the public portal for the purpose of private study or research.

- You may not further distribute the material or use it for any profit-making activity or commercial gain

- You may freely distribute the URL identifying the publication in the public portal.

If the publication is distributed under the terms of Article 25fa of the Dutch Copyright Act, indicated by the "Taverne" license above, please follow below link for the End User Agreement:

www.tue.nl/taverne

Take down policy

If you believe that this document breaches copyright please contact us at:

openaccess@tue.nl

providing details and we will investigate your claim. 
Conclusion: We have demonstrated the possibility of frequency hopping between the fundamental frequency and third harmonic of a Love wave device during the deposition and removal of a biological mass layer. The optimum interdigital transducer metallisation and guiding layer thickness for simultaneous operation at these frequencies has been investigated.

Acknowledgment: The authors gratefully acknowledge the financial support of BBSRC provided by research grant 301/E11140.

\section{(C) IEE 2001}

Electronics Letters Online No: 20010243

7 December 2000

DOI: $10.1049 / \mathrm{el} \cdot 20010243$

M.I. Newton, F. Martin and G. McHale (Department of Chemistry and Physics, The Nottingham Trent University, Clifton Lane, Nottingham, NG11 8NS, United Kingdom)

E-mail: michael.newton@ntu.ac.uk

K. Melzak and E. Gizeli (Institute of Biotechnology, University of Cambridge, Tennis Court Road, Cambridge, CB2 IQT, United Kingdom)

\section{References}

1 GULYAEV, Y.V.: 'Review of shear surface acoustic waves in solids', IEEE Trans. Ultrason. Ferroelectr. Freq. Control, 1998, 45, pp. $935-938$

2 GIZELI, E, STEVENSON, A.C., GODDARD, Y.J. and LOWE, C.R.: "A novel Love-plate acoustic sensor utilizing polymer overlayers', IEEE Trans. Ultrason. Ferroelectr. Freq. Control, 1992, 39, pp. 657-659

3 HERMANN, F., HAAN, D., and BUTTGENBACH, S.: 'Separation of density and viscosity influence on liquid-loaded surface acoustic wave devices', Appl. Phys. Lett., 1999, 74, pp. 3410-3412

4 JACOBY, B., and VELLEKOOP. M.J.: "Viscosity sensing using a Lovewave device', Sens. Actuators A, Phys., 1998, 68, pp. 275-281

5 WEISS, M., WELSCH, W. SCHICKFUS, M.V., and HUNKLINGER, S.: 'Viscoelestic behavior of antibody films on shear horizontal acoustic surface wave sensors', Anal. Chem., 1998, 70, pp. 28812887

6 JACOBY, B., and VELLEKOOP, M.J.: 'Analysis and optimization of Love wave liquid sensors', IEEE Trans. Ultrason. Ferroelectr. Freq. Control, 1998, 45, pp. 1293-1302

7 HARDING, L.G., and DU, J.: 'Design and properties of quartz-based Love wave acoustic sensors incorporating silicon dioxide and PMMA guiding lavers', Smart Mater. Struct., 1997, 6, pp. 716-720

8 GIZEL., E., LOWE, C.R., LILEY, M., and VOGEL, H.: 'Detection of supported lipid layers with the acoustic Love waveguide device: application to biosensors', Sens. Actuators B, Chem., 1996, 34, pp. 295-300

9 BAER, R.L., and FLORY, C.A.: 'Harmonic operation of STW filters'. IEEE Symp. Ultrasonics, 1988, pp. 53-56

\section{Temperature retrieval algorithm for brain temperature monitoring using microwave brightness temperatures}

\section{G.M.J. Van Leeuwen, J.W. Hand, J.B. Van de Kamer} and S. Mizushina

A solution to the inverse problem of retrieving temperature from a set of microwave brightness temperatures together with a priori information regarding weighting functions and heat transfer within the infant head is introduced. The method offers the basis for non-invasive temperature monitoring appropriate for hypothermal neural rescue therapy.

Introduction: Cooling of the brain after asphyxia at birth reduces the development of brain damage [1]. Clinical trials investigating the efficacy of brain cooling require that temperatures in the deep brain can be monitored. We are developing a microwave radiometry (MWR) system with five frequency bands for the non-invasive and prolonged monitoring of deep brain temperature [2]. Here we report an improved method for retrieving tissue temperatures from MWR measurements, and examine how uncertainties in measured brightness temperatures and in the data used in the analysis affect the retrieved temperatures.
Microwave radiometry: The measured brightness temperature in MWR is defined by the tissue's thermal radiation and is, according to the Rayleigh-Jeans law, proportional to the absolute temperature:

$$
T_{B, i} \equiv \frac{P_{i}}{k \Delta f_{i}}=\iiint_{a f v} W_{i}(\mathbf{r}) T(\mathbf{r}) d V
$$

where $P_{i}$ is the thermal power received by the radiometer's antenna in a bandwidth $\Delta f_{i}$ centred around frequency $f_{i}$, and $k$ is Boltzmann's constant. The rightmost term involves integration over the antenna's field of view (afv) of the product of absolute temperature $T$ and the radiometric weighting function $W_{i}$. The frequency dependence of $W_{i}$ allows extraction of the temperaturedepth profile in the tissue from a set of measurements made at different frequencies.

The radiometer antenna is a ceramic loaded open-ended rectangular waveguide. A thin water bolus between the antenna and the baby's head ensures predictable coupling. Each of five receivers, with central frequencies $1.2,1.65,2.3,3.0$, and $3.6 \mathrm{GHz}$ and $0.4 \mathrm{GHz}$ bandwidth, contains a reference noise source that is temperature controlled so as to 'balance' the thermal noise radiation from the antenna. When this condition is met, the brightness temperature of the tissues under observation is equal to that of the reference noise source [3]. For our system, which uses integration times of 4 or $5 \mathrm{~s}$, we have calculated the total uncertainty in the measurement of the brightness temperatures to range between $60 \mathrm{mK}$ for the $1.2 \mathrm{GHz}$-centred band and $65 \mathrm{mK}$ for the $3.6 \mathrm{GHz}$ centred band.

Modelling: To calculate brightness temperatures, the weighting functions and temperature distribution must be determined. Electromagnetic and thermal computations were carried out using a 3D anatomically realistic model of an infant head. The radiometric weighting function was found using the reciprocity theorem by calculating the normalised power absorption rate distribution when the antenna was operating as a source rather than as a receiver:

$$
W_{i}(\mathbf{r})=\frac{(1 / 2) \sigma_{i}\left|\mathbf{E}_{i}(\mathbf{r})\right|^{2}}{\iiint_{a f v}(1 / 2) \sigma_{i}\left|\mathbf{E}_{i}(\mathbf{r})\right|^{2} d V}
$$

where $\mathbf{E}_{i}$ is the electric field intensity induced by the antenna and $\sigma_{i}$ is the tissue conductivity. The FDTD method with retarded time absorbing boundary conditions [4] was used to calculate the E-field distributions. Excitation of the antenna was modelled by prescribing $\mathbf{E}$-field values for all voxels in the respective probe plane of the waveguide antenna. Temperature distributions within our infant head model were calculated using the heatsink approach [5] and were validated by comparison with those derived using a model that accounted for the effects of discrete vasculature [6]. The base set of thermal boundary conditions represented a cooling cap at $16^{\circ} \mathrm{C}$ and body core temperature maintained at $34^{\circ} \mathrm{C}$

Temperature retrieval: The inverse problem of finding the best estimate for the temperature distribution requires parameterisation of the 3D temperature distribution. In view of the long computation time necessary to calculate a temperature distribution, varying a parameter in the thermal model is not an option for real-time temperature retrieval. Instead, we use pre-calculated distributions $T_{1}$, $T_{2}, \ldots$ :

$$
T_{\text {retrieved }}(\mathbf{r})=T_{0}+p_{1}\left(\Delta T_{1}(\mathbf{r})\right)+p_{2}\left(\Delta T_{2}(\mathbf{r})\right)+\cdots
$$

where $T_{0}$ is the cooling cap temperature, $\Delta T_{i}=T(\mathbf{r})-T_{0}$, and the $p_{i}(T)$ are polynomial functions, the coefficients of which are the parameters to be determined. The parameters can now be taken outside of the volume integral in eqn. 1, which allows the volume integration of the product of weighting function and temperature to be performed before measurements start. For example, two precalculated temperature distributions can be used with dimensionless parameters $a_{1}$ and $a_{2}$ which scale the distributions:

$$
T_{\text {retrieved }}\left(\mathbf{r} \mid a_{1}, a_{2}\right)=T_{0}+a_{1} \Delta T_{1}(\mathbf{r})+a_{2} \Delta T_{2}(\mathbf{r})
$$

The numerical brightness temperatures can then be written as

$$
T_{B, i}\left(a_{1}, a_{2}\right)=T_{0}+a_{1} \iiint \Delta T_{1} W_{i} d V+\iiint \Delta T_{2} W_{i} d V
$$


Solution of the inverse problem is now reduced to solving an overdetermined system of linear equations.

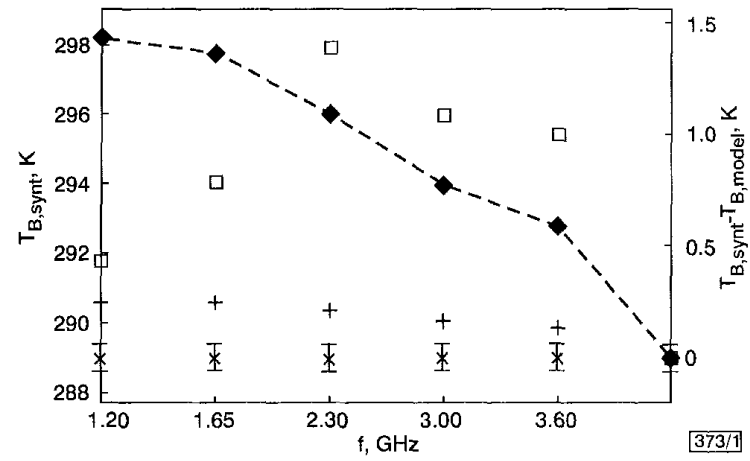

Fig. 1 Synthetic brightness temperatures for perfusion $40 \mathrm{ml}(100 \mathrm{~g})^{-1}$ min $^{-1}$; differences with perfusion $30 \mathrm{ml}(100 \mathrm{~g})^{-1} \mathrm{~min}^{-1}$ and difference with best fit

- - synthetic brightness, bolus $5 \mathrm{~mm}$ (scale on left axis)

$+\quad$ base, bolus $5 \mathrm{~mm}$ (scale on right axis)

base 2 , bolus $7 \mathrm{~mm}$ (scale on right axis)

fit with uncertainty, $T_{B, s y t}-T_{B \text { model }}$ (scale on right axis)

Accuracy: Reconstruction of the temperature distribution from synthetic brightness temperatures calculated using the same models and parameters simulates the ideal situation in which exact knowledge of the spatial distributions of all the relevant physical properties used in the electromagnetic modelling and thermal modelling is available. Because no information is discarded in our new temperature retrieval process, it results in perfect retrieval for this ideal case. By using this method, we can investigate how the uncertainties in the brightness temperatures affect the precision of the reconstructed temperatures.

We have retrieved temperatures using two different brain perfusion values $\left(30\right.$ and $40 \mathrm{ml}(100 \mathrm{~g})^{-1} \mathrm{~min}^{-1}$ ) to calculate temperature distributions. The central brain temperatures are equal, so when we use the parameterisation

$$
T_{\text {retrieved }}\left(\mathbf{r} \mid a_{1}, a_{2}\right)=T_{0}+a_{1} \Delta T_{1}(\mathbf{r})+a_{2}\left(T_{2}(\mathbf{r})-T_{1}(\mathbf{r})\right)
$$

the standard error in $a_{1}, \sigma_{a 1}$, alone determines the standard error: in the central brain temperature. With synthetic brightness temperatures from $T_{1}$ we find $a_{1}=1, \sigma_{a 1}=0.041$, resulting in $\sigma_{T, b r u i n}=$ $0.75^{\circ} \mathrm{C}$ for $\Delta T_{1}(\mathbf{r})=18.25^{\circ} \mathrm{C}$ in the central brain.

Solving the inverse problem for a set of brightness temperatures calculated for the different body core temperature of $37^{\circ} \mathrm{C}$ instead of $34^{\circ} \mathrm{C}$ (using the same $T_{1}$ and $T_{2}$ as before) results in $a_{1}=1.164$ \pm 0.041 . This corresponds exactly to the difference in calculated temperatures with respect to $T_{0}\left(\Delta T=21.25^{\circ} \mathrm{C}\right.$ and $18.25^{\circ} \mathrm{C}$, respectively, for high and low core temperature). This is a reflection of the fact that the shapes of the temperature profiles are virtually independent of the temperature difference between cap and body core.

Inaccurate data causes systematic errors in the retrieved temperature distribution. We have evaluated the effect of realistic deviations in several parameters by solving the inverse problem for synthetic brightness temperatures. In practice, the parameter uncertainty with the biggest influence can be countered by using modelling results for different values of this parameter. We found that the thickness of the cooled water bolus is a major possible source of error. Therefore, the temperature retrieval might be based on sets of model computations for different bolus thicknesses. The effect of inaccurate values of other parameters in case of analysis using different bolus thicknesses was investigated. Assuming brain perfusion $30 \mathrm{ml}(100 \mathrm{~g})^{-1} \mathrm{~min}^{-1}$, a fit to synthetic brightness temperatures obtained for brain perfusion $40 \mathrm{ml}^{(100 \mathrm{~g})^{-1}}$ min $^{-1}$ resulted in an overestimate of the central brain temperature by $0.5^{\circ} \mathrm{C}$. Fig. 1 shows the retrieved profile fits the synthetic data very well in this case. Plausible inaccuracies in dielectric properties $(\sim 10 \%)$ had a smaller effect, but a different anatomical segmentation with $2 \mathrm{~mm}$ more bone resulted in a $2^{\circ} \mathrm{C}$ underestimate.

Conclusion: A new algorithm for temperature retrieval fiom a set of microwave brightness temperatures is introduced. It allows the time consuming calculations of temperature distributions and weighting functions to be performed off line, reducing the solution of the inverse problem to the solution of an overdetermined system of linear equations. Use of the algorithm, together with numerical modelling in an anatomically realistic model of the infant head, enables the temperature distribution in the brain to be obtained quickly from measurements obtained using a multi-frequency microwave radiometer. The algorithm is also useful in performing an error analysis of this measurement technique.

Acknowledgments: This work was supported in part by project grants from the UK Engineering and Physical Sciences Research Council (EPSRC) and the Garfield Weston Foundation. We are grateful to S.N. Hornsleth, Haukeland Hospital, Bergen, for providing the FDTD code used in this work and to J.J.W. Lagendijk, University of Utrecht, K. Maruyama, Research Institute of Electronics, Shizuoka University, Hamamatsu, and A.D. Edwards and D. Azzopardi, Imperial College School of Medicine, London for helpful discussions.

(C) IEE 2001

Electronics Letters Online No: 20010269

16 Jamuary 2001

DOI: $10.1049 / \mathrm{el}: 20010260$

G.M.J. Van Leeuwen and J.W. Hand (Radiological Sciences Unit Department of Imaging, Imperial College School of Medicine Hammersmith Campus, Du Cane Road, London W12 ONN United Kingdom)

J.B. Van de Kamer (Department of Radiotherapy, University Medical Center, Heidelberglain 100, 3584 CX Utrecht, The Netherlands)

S. Mizushina (TAO Hamamatsu Lifeline Research Center, Shizuoka. 432-8061, Japain

\section{References}

I EDWARDS, A.D., WYATT, J.S., and THORESEN, M.: "Treatment of hypoxic-ischaemic brain damage by moderate hypothermia', Arch. Dis. Child, 1998, 78, (2), pp. F85-88

2 MIZUSHINA, S, MARUYMA, K., SUGIURA, T, VAN LEEUWEN, G.M.J, HAND, J.W., MARROCCO, G., BARDATI, F, TDWARDS, A.D, AZZOPARDI, D.V., and LAND, D.: "Algorithm for retrieval of deep brain temperature in new-born infant from microwave radiometric data'. IEEE MTT-S Int. Microwave Symp. Dig., 2000, pp. 1033 1036

3 WAIT, D.F., and NEMOTO, T.: 'Measurement of the noise temperature of a mismatched noise source', IEEE Trans. Microwave Theory Tech., 1968, 16, (9), pp. 670-675

4 BERNTSEN, S., and HORNSLETH, S.N.: 'Retarded time absorbing boundary conditions', IEEE Trans. Antennas Propag., 1994, 42, (8), pp. 1059-1064

5 PENNES, H.H.: 'Analysis of tissue and arterial blood temperature in the resting human forearm', J. Appl. Physiol, 1948, 1, pp. 93-122

6 VAN LEEUWEN, G.M.J., HAND, J.W., LAGENDUK, J.J.W, AZZOPARDI.D.V., and EDWARDS. A.D.: "Numerical modeling of temperature distributions within the neonatal head', Pediatr. Res., $2000,48,(3)$, pp. $351-356$

\section{Optimisation chaotic synchronisation of length-limited noisy Chua's circuit signal}

Di He, Chen He, Ling-ge Jiang, Hong-wen Zhu and Guang-rui $\mathrm{Hu}$

A new approach to synchronisation of Chua's circuit is presented. It effectively combines the interior penalty method of optimisation and chaotic synchronisation. Even under unfavourable, noisy conditions, the approach shows attractive lower variance results, compared with conventional chaotic synchronisation in realising the synchronisation of length-limited noisy chaotic signals.

Introduction: Chatic signals commonly have stochastic noise phenomena present in the time domain, which cannot be easily synchronised. Conventional chaotic synchronisation, which was first introduced by Pecora and Carroll [1,2], is an efficient means of resolving this problem but it is only available under specific conditions, while in unfavourable environments with additive white 